\title{
MONITORING OF SULFUR DIOXIDE IN THE GUINEA SAVANNA ZONE OF NIGERIA: IMPLICATIONS OF THE ATMOSPHERIC PHOTOCHEMISTRY
}

\author{
A.M.O. Abdul Raheem ${ }^{1 *}$, F.A. Adekola ${ }^{1}$ and I.B. Obioh ${ }^{2}$ \\ ${ }^{1}$ Department of Chemistry, University of Ilorin, P.M.B. 1515, Ilorin, Nigeria \\ ${ }^{2}$ Centre for Energy Research and Development, Obafemi Awolowo University, Ile-Ife, Nigeria
}

(Received December 2, 2008; revised May 16, 2009)

\begin{abstract}
The level of sulfur(IV) oxide $\left(\mathrm{SO}_{2}\right)$ in the tropospheric environment of Ilorin is presented using three urban classes and a control site from 2003-2006 wet and dry seasons. The mean concentrations over the years during wet and dry seasons were $1.29 \pm 0.17$ and $7.17 \pm 0.87(\mathrm{ppb})$, respectively. The wet season concentration was $15.25 \%$ lower than the dry season due to rain attenuation. The mean values at the control site for two seasons were one order of magnitude lower than those in the urban sites. The overall average concentration over Ilorin city was $4.23 \pm 0.52 \mathrm{ppb}$. The value is comparable with other cities of the world and is within the limit of the United State Environmental Protection Agency (USEPA) Guidelines for Air Quality Standards. $\mathrm{SO}_{2}$ levels were found to varied significantly with vehicular intensity, other anthropogenic activities also decreased drastically during wet season. There was a significant difference $(\mathrm{p}=0.05)$ between $\mathrm{SO}_{2}$ concentration with high and low traffic flow count; however, there was no difference $(\mathrm{p}=0.05)$ between high traffic/medium population and medium traffic/high population density areas. The regression analysis indicated a correlation between $\mathrm{SO}_{2}$ and the hourly traffic volume in almost all the sites.
\end{abstract}

KEY WORDS: Atmospheric photochemistry, Sulfur dioxide, Air pollution, Monitoring, Assessment

\section{INTRODUCTION}

Environmental pollution is one of the causes of deteriorating living conditions as the breathing of safe air is as important as safe water or food, however the human population in developing countries are compelled to breath polluted air from biomass combustion [1] and other diffused sources. Sources of air pollution are diverse and it is impossible to discriminate between domestic and traffic sources often surrounded by industrial or heat sources. Although sulfur dioxide is not a "greenhouse gas", its presence in the atmosphere may influence climate $[2,3]$. $\mathrm{SO}_{2}$ can react with a variety of photochemically produced oxidants to form sulfate aerosols [4]. The concentrations of these particulates are increasing due to the burning of sulfur containingfossil fuels. Anthropogenic $\mathrm{SO}_{2}$ emissions world-wide amount to 70-80 million tones per year [5], while the natural emissions have been estimated to be 18-70 million tones per year [6]. More than $80 \%$ of anthropogenic $\mathrm{SO}_{2}$ arises from fuel combustion, with three-quarters of this from coal [5, 7]. The global sulfur cycle have been summarized [4, 8]. The cycle involves primarily $\mathrm{H}_{2} \mathrm{~S}, \mathrm{SO}_{2}$ and sulfates. About 65 million tons of $\mathrm{SO}_{2}$ is produced per year from combustion of fossil fuels [3, 4] which accounts for less than $33 \%$ for total anthropogenic activities while the remaining $67 \%$ due to volcanic activities and other natural sources over which there is no control [4]. However, the highest source of sulfur entering the atmosphere is 106 million tons of $\mathrm{H}_{2} \mathrm{~S}$ annually originating from the decay of organic matter and the biological reduction of sulfates especially by anaerobic bacteria $[3,4]$. The $\mathrm{H}_{2} \mathrm{~S}$ is rapidly converted in the atmosphere to $\mathrm{SO}_{2}$ by the following overall process reaction $[4,9]$ :

$2 \mathrm{H}_{2} \mathrm{~S}+3 \mathrm{O}_{2} \rightarrow 2 \mathrm{SO}_{2}+2 \mathrm{H}_{2} \mathrm{O}$

In the air over the United States between 250 and 300 million was estimated yearly as air pollutants as a result of human activities while the annual emission estimate for sulfur(IV) is put at 130 million tones $[4,10]$. A statistically significant rise in deaths was found in New York

*Corresponding author. E-mail: faadekola@yahoo.fr 
City and Mexico with increase levels of $\mathrm{SO}_{2}$ and a corresponding decrease, following washout of this pollutant by rainfall $[11,12]$. During a five-day period marked by temperature inversion and fog in London in 1952, between 3,500 and 4,000 deaths in excess of normal occurred with $1.3 \mathrm{ppm} \mathrm{SO}_{2}$ level recorded $[3,12]$.

$\mathrm{SO}_{2}$ is oxidized to $\mathrm{SO}_{3}$ in the atmospheric air by photolytic and catalytic processes involving ozone, oxides of nitrogen $\left(\mathrm{NO}_{\mathrm{x}}\right)$, and hydrocarbon $(\mathrm{HC})$, giving rise to the formation of photochemical smog [4]. Under normal conditions of the atmosphere, $\mathrm{SO}_{3}$ reacts with $\mathrm{H}_{2} \mathrm{O}$ vapour to produce droplets of $\mathrm{H}_{2} \mathrm{SO}_{4}$ aerosol which give rise to the so called 'acid rain' causing damage to vegetation and materials $[13,14]$. The tetraoxosulfate(VI) acid and sulfate aerosols present in the urban air are smaller than $2 \mu \mathrm{m}$ [4], hence can easily reach the pulmonary region of the lungs, causing respiratory problem. It has been shown that ammonium sulfates and ammonium bisulfates are predominant compounds in the light-scattering, sub-micrometer particulate aerosol encountered around St. Louis [15], however, the potential of sulfate to induce climate change is high.

In contrast to $\mathrm{NO}_{2}, \mathrm{SO}_{2}$ is deleterious to plant life [16, 14]. Air pollution causes the decline in Eastern Europe [17, 18]. Area with extensive large-scale forest decline correlate with the areas where $\mathrm{SO}_{2}$ concentration were elevated $[19,14]$.

If the concentration of $\mathrm{SO}_{2}$ is higher along with other gaseous pollutants in the troposphere and continues to accumulate over time, the overall concentration can have a negative effect on health, vegetation and structures [9]. Preliminary data covering the dry season of 2003 had earlier been reported [20]. This work presents comprehensive data on the level of $\mathrm{SO}_{2}$ monitored over three years, from 2003-2006 in Ilorin, a city in the Guinea Savanna Zone of Nigeria. The implication of $\mathrm{SO}_{2}$ trend on the atmospheric photochemistry of Ilorin air shed was also discussed.

\section{EXPERIMENTAL}

Study Area. The Nigerian city of Ilorin is located on latitude $8^{\circ} 20^{\prime} \mathrm{N}$ and longitude $4^{\circ} 35^{\prime} \mathrm{E}$, at an approximate altitude of $306 \mathrm{~m}$ above the sea level [9]. It is about $500 \mathrm{~km}$ South-West of Abuja, the Federal Capital City of Nigeria, and is located in the Guinea Savannah belt of Nigeria. As a result of her location, Ilorin experiences two seasons: the dry and the wet. The persistence of season is influenced by the fraction of time during an annual cycle that the line of the Inter-Tropical Convergence Zone (ITCZ) or the Inter-Tropical Discontinuity (ITD), is below or above her line of latitude. The dry season (under the influence of the north-east trade winds, when the ITD is south of the city), on the average, starts around the middle of October and lasts until the middle of April of the following year, though more pronounced between mid November and mid February. Rains initiated by predominance of southwest monsoon winds in the area, dominates the remaining six months of the year when the ITD lies north of the city. The dry season period is characterized, not only by near absence of rain, but dust haze from the Sahara Desert. The winds are cold because they form part of the Hadley cell, moving equator-ward from the poles at ground levels, and pole-ward from the equator at upper levels. The Harmattan period, being wintertime in Europe, implies that cold air, from Europe through the Sahara, arrives in the sub-region, carrying the Sahara dusts. The season is characterized by high atmospheric turbidity, which inhibits the penetration of the solar radiation to the earth's surface.

The city is semi-industrial with a relatively large urban centre with little presence of large industries that could qualify as major point sources. Apart from the few industries, the rest of the city is dominated by mobile sources from the expanse of road network across the city, and area sources, which are a mix of residential, commercial, medium and small scale industries. As 
for other major cities in the country, no strict demarcation exists between industrial, residential and commercial areas.

Choice of sampling sites. The sampling locations were selected across the city to reflect the following categories of interest: (1) medium population density/high traffic volume (MPD-HT) zones, (2) high population density/medium traffic volume (HPD-MT) zones, (3) industrial area/low traffic volume (IA-LT) zones, and (4) low population density/very low traffic volume (LPD-VLT) zone was used as control (CTR).

Sampling. A high volume sampler was used [9]. The vacuum pump draws air from the atmosphere into sampling solution in a bubbler tube at a flow rate of $1000 \mathrm{~mL} / \mathrm{min}$. The volume of the absorbing solution used was $30 \mathrm{~mL}$ to ensure that enough sample dissolved in the absorbing solution based on their low concentration in the atmosphere. All joints in the sampling train were airtight using silicon grease. Sampling was undertaken at 60 min intervals; after which, the bubbler was removed and the absorbent solution transferred into sample bottle for analysis. The hourly sampling was for ten hours from the early dawn through afternoon to later part of evening (6:00 AM - 6:00 PM).

$\mathrm{SO}_{2}$ concentration was determined by conductometric method [3, 4]. The results of various measurements were validated using the LaMotte Air Sampling Pump Model BD (Figure 1) and Test Reagent Kits supplied [21]. The absorbing solution for trapping $\mathrm{SO}_{2}$ was $0.3 \mathrm{M} \mathrm{H}_{2} \mathrm{O}_{2}$ solution buffered at $\mathrm{pH} 5 \pm 0.2$ to disallow dissolution of carbon(IV) oxide from the atmosphere. The standard solution and calibration curve were prepared. The calibration curve was used as a working curve for the determination of $\mathrm{SO}_{2}$ during the analysis of samples.

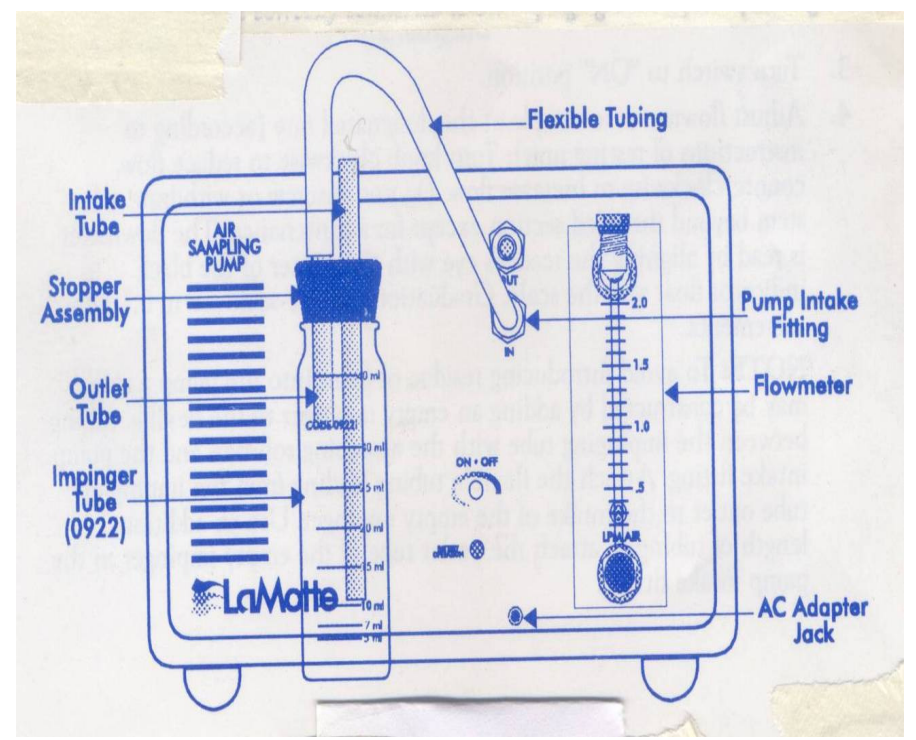

Figure 1. LaMotte Air-Sampler.

\section{RESULTS AND DISCUSSION}

Establishment of atmospheric concentration. Conductivity measurements were undertaken using the Hanna Instrument Model E 214 conductivity meter. The molar concentrations of 
$\mathrm{H}_{2} \mathrm{SO}_{4}$ formed from $\mathrm{SO}_{2}$ of the samples were read from the calibration curve, the molar concentrations obtained were converted into part per billion (ppb) using conversion factors. Equation of reaction for the formation of $\mathrm{H}_{2} \mathrm{SO}_{4}$ from $\mathrm{SO}_{2}$ is:

$$
\mathrm{SO}_{2(\mathrm{~g})}+\mathrm{H}_{2} \mathrm{O}_{2(\mathrm{aq})} \rightarrow \mathrm{H}_{2} \mathrm{SO}_{4}(\mathrm{aq})
$$

The pollutant concentration range, the mean and the average vehicular volume (Avv) at various sites during the seasons are as given in Table 1.

Table 1. Average concentrations (ppb) of $\mathrm{SO}_{2}$ at all sites during dry and wet seasons (2003-2006) in Ilorin, Nigeria.

\begin{tabular}{|c|c|c|c|c|c|c|}
\hline \multirow{2}{*}{ Site } & \multicolumn{3}{|c|}{ Dry season } & \multicolumn{3}{c|}{ Wet season } \\
\cline { 2 - 7 } & Mean & Range & Avv & Mean & Range & Avv $^{*}$ \\
\hline 1 & $8.05 \pm 1.41$ & $4.86-11.24$ & 2976 & $2.23 \pm 0.41$ & $1.32-3.15$ & 1917 \\
\hline 2 & $5.69 \pm 0.99$ & $3.44-7.94$ & 2202 & $1.33 \pm 0.35$ & $0.54-2.12$ & 1240 \\
\hline 3 & $13.35 \pm 1.4$ & $10.20-16.51$ & 474 & $0.77 \pm 0.14$ & $0.45-1.08$ & 857 \\
\hline 4 & $1.58 \pm 0.42$ & $0.64-2.53$ & 5 & $0.83 \pm 0.19$ & $0.40-1.27$ & 1 \\
\hline
\end{tabular}

*Avv-Average vehicular volume.

Table 2 compares the concentrations of $\mathrm{SO}_{2}$ at different sites in Ilorin during the two seasons. There were increases in all the pollutants concentration during dry season, however, the order of pollutant concentrations decreases as follows: $3>1>2>4$ during dry season while the order of decreased in the concentration of the pollutant during the wet season is as follows: $1>$ $2>4>3$. Site 3 has the highest during dry season due to the activities within the area (industries, vehicles, refuse dump). This dump was on fire during the sampling periods, although the atmospheric conditions (low wind and low level inversion) favour the formation of $\mathrm{H}_{2} \mathrm{SO}_{4}$ through $\mathrm{SO}_{2}$ which is suspected to take part in the smog formation by getting its concentration reduced while that of ozone increased according to the following equations [4]:

$$
\begin{aligned}
& \mathrm{SO}_{2}+\mathrm{hv} \rightarrow \mathrm{SO}_{2} \\
& \mathrm{SO}_{2}+\mathrm{O}_{2} \rightarrow \mathrm{SO}_{4} \\
& \mathrm{SO}_{4}+\mathrm{O}_{2} \rightarrow \mathrm{SO}_{3}+\mathrm{O}_{3} \\
& \mathrm{SO}_{3}+\mathrm{H}_{2} \mathrm{O} \rightarrow \mathrm{H}_{2} \mathrm{SO}_{4}
\end{aligned}
$$

Table 2. Mean day time concentrations (ppb) of $\mathrm{SO}_{2}$, at urban sites in Ilorin during both seasons (20032006).

\begin{tabular}{|l|c|c|}
\hline Urban site type & Dry & Wet \\
\hline HT-MPD & $8.05 \pm 1.41$ & $2.23 \pm 0.41$ \\
\hline MT-HPD & $5.69 \pm 0.99$ & $1.33 \pm 0.35$ \\
\hline IA-LT & $13.35 \pm 1.4$ & $0.77 \pm 0.14$ \\
\hline CTR & $1.58 \pm 0.42$ & $0.83 \pm 0.19$ \\
\hline
\end{tabular}

However, this photochemical oxidation of $\mathrm{SO}_{2}$ to $\mathrm{H}_{2} \mathrm{SO}_{4}$ aerosol is accelerated in the presence of olefinic hydrocarbon and oxides of nitrogen present in the photochemical smog [4].

Table 3 summarizes the time variation of mean concentrations ( $\mathrm{ppb}$ ) of $\mathrm{SO}_{2}$ during the two seasons. The observed decrease in concentration pattern noticed from dry to wet season could be attributed to rain attenuation because of solubility of $\mathrm{SO}_{2}$. However, the daily pattern from 6:00 AM to 6:00 PM of this pollutant is evident of anthropogenic activities occurring in Ilorin during the two seasons. 
Table 3. Time variation of mean concentrations ( $\mathrm{ppb}$ ) of $\mathrm{SO}_{2}$ during dry and wet seasons.

\begin{tabular}{|c|c|c|}
\hline Sampling time & Dry & Wet \\
\hline 6:30-7:30 AM & 7.83 & 0.68 \\
\hline 7:45-8:45 AM & 6.54 & 0.45 \\
\hline 9:00-10:00 AM & 4.17 & 1.8 \\
\hline 10:15-11:15 AM & 4.42 & 1.07 \\
\hline 11:30-12:30 PM & 6.27 & 1.35 \\
\hline 12:45-1:45 PM & 7.36 & 1.3 \\
\hline $2: 00-3: 00$ PM & 8.84 & 1.69 \\
\hline $3: 15-4: 15$ PM & 7.62 & 1.52 \\
\hline $4: 30-5: 30$ PM & 9.52 & 1.63 \\
\hline 5:45-6:45 PM & 9.11 & 1.41 \\
\hline
\end{tabular}

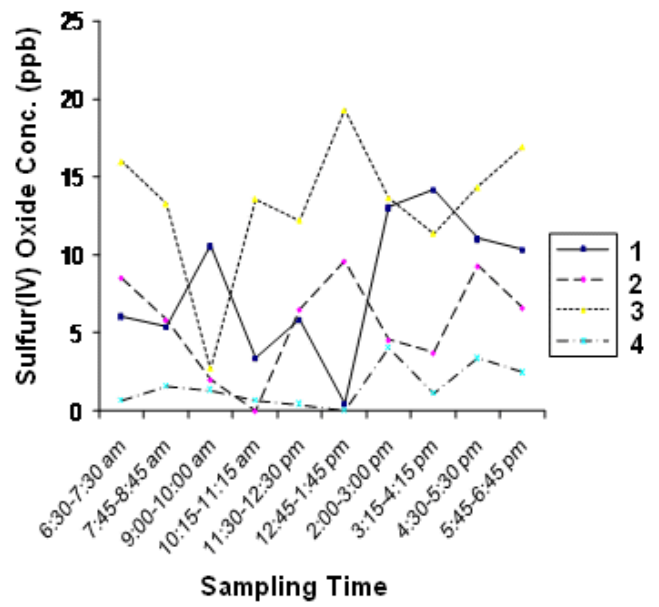

Figure 2. Time variation of daily average concentration of sulfur(IV) oxides in Ilorin town during dry season.

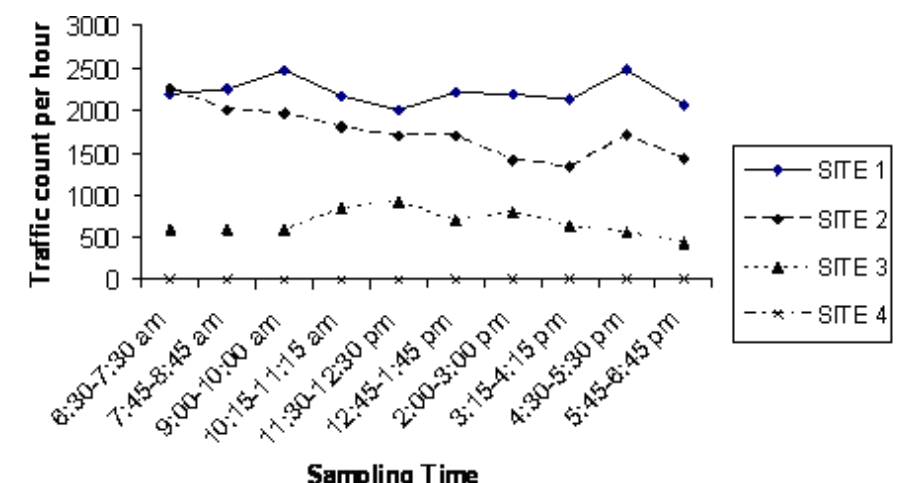

Sampling Time

Figure 3. Variation of the average traffic count with the time of the day in Ilorin during dry season.

Bull. Chem. Soc. Ethiop. 2009, 23(3) 
As shown in Figures 2-5, the continuous increase and decrease pattern at different time of the day corresponded to volume of vehicle and other anthropogenic activities occurring. The effect of man made activities in terms of $\mathrm{SO}_{2}$ contribution is more in urban and industrial atmosphere. However, this effect is felt more during the dry than the wet season. $\mathrm{The}^{\mathrm{SO}} \mathrm{S}_{2}$ in the atmosphere at specific point on time depend on automobile exhaust and on other anthropogenic activities $[20,11]$ happening at the time of interest and the weather conditions. The role of $\mathrm{SO}_{2}$ depends on the meteorological conditions [22]. Therefore depending on the weather conditions, $\mathrm{SO}_{2}$ could have a negative or positive role to the ozone $\left(\mathrm{O}_{3}\right)$ formation. For example the overall regression results showing constants with ozone as a dependant variable for Ilorin during the wet and dry seasons in terms of the interaction between and within ozone, oxides of nitrogen and sulfur(IV) oxide in equation 7 and 8 respectively. Acting in concert rather than alone, $\mathrm{SO}_{2}$ can have detrimental effect on health, structures and plants $[9,23]$.

$$
\begin{aligned}
& {\left[\mathrm{O}_{3}\right]=30.76+1.09\left[\mathrm{SO}_{2}\right]-3.11\left[\mathrm{NO}_{\mathrm{x}}\right]} \\
& {\left[\mathrm{O}_{3}\right]=60.48-4.25\left[\mathrm{NO}_{\mathrm{x}}\right]-2.71\left[\mathrm{SO}_{2}\right]}
\end{aligned}
$$

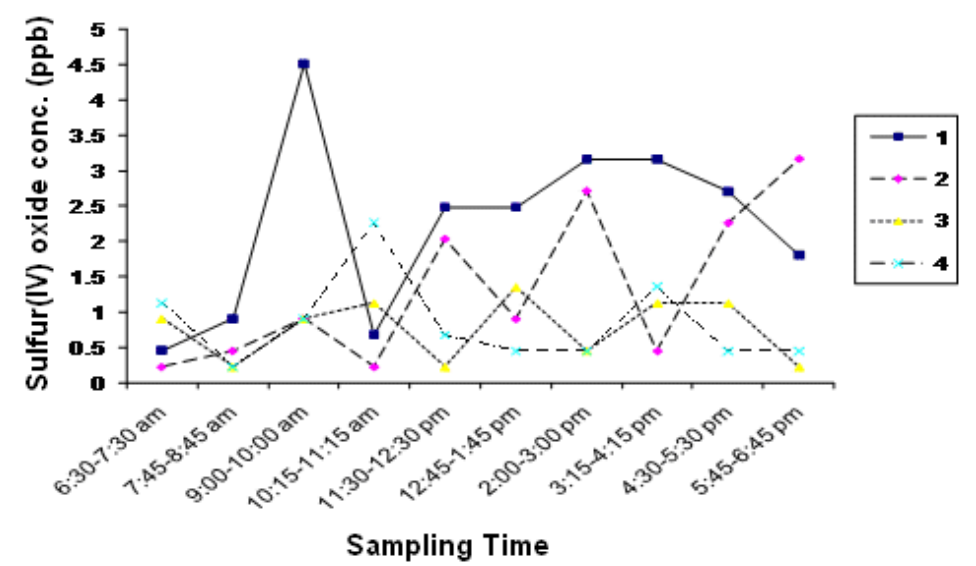

Figure 4. Time variation of daily average concentration of sulfur(IV) oxide in Ilorin town during wet season.

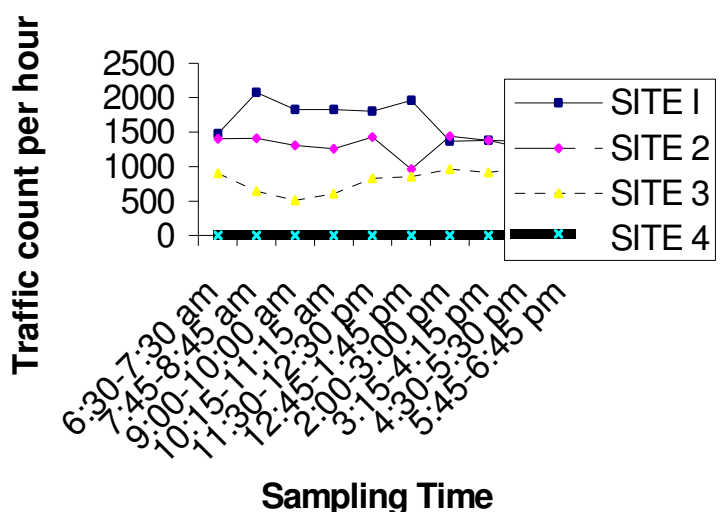

Figure 5. Variation of the average traffic count with the time of the day in Ilorin during wet season. 
Equation 7 reveals a positive contribution by $\mathrm{SO}_{2}$ and a negative contribution with higher slope by $\mathrm{NO}_{x}$ to the overall concentration of $\mathrm{O}_{3}$ in the ambient air of Ilorin, however similar observation has been reported [24]. From equation 8, it is clear that $\mathrm{SO}_{2}$ has a negative contribution with higher slope during dry season to the air shed of Ilorin.

Table 4 compares Ilorin mean $\mathrm{SO}_{2}$ level within the two seasons with some national air quality standards and measured values. The measured value observed in this study is comparable and low when compared to another city in Nigeria, e.g. Ibadan [10].

Table 4. Ilorin city sulfur(IV) oxide level (average of the two seasons), compared to some national air quality guidelines/measured values.

\begin{tabular}{|l|l|l|}
\hline Country/organization/city & Guide line value, $\mu \mathrm{gm}^{-3} / \mathrm{ppb}$ & Averaging time \\
\hline WHO [25] & $125 / 47.5$ & $24 \mathrm{~h}$ \\
\cline { 2 - 3 } & $50 / 19.1$ & $1 \mathrm{y}$ \\
\hline \multirow{2}{*}{ European Union (EU) [26] } & $100-150 / 38.2-57.3$ & $24 \mathrm{~h}$ \\
\cline { 2 - 3 } & $40-60 / 15.3-22.9$ & $1 \mathrm{y}$ \\
\hline USA [27] & $364 / 139$ & $24 \mathrm{~h}$ \\
\cline { 2 - 3 } & $78 / 29.8$ & $1 \mathrm{y}$ \\
\hline Nigeria [28] & $260 / 99.3$ & $1 \mathrm{~h}$ \\
\cline { 2 - 3 } & $26 / 9.9$ & $24 \mathrm{~h}$ \\
\hline Japan [29] & $104 / 39.7$ & $24 \mathrm{~h}$ \\
\hline UK [30] & $266 / 101.6$ & $0.25 \mathrm{~h}$ \\
\hline Central Berlin [30] & $120 / 45.8($ mean) & $1 \mathrm{y}$ \\
\hline Pakistan [31] & $137.42 / 52.5(m e a n)$ & $1 \mathrm{~h}$ \\
\hline Ibadan [10] & $34.1 / 13($ mean) & $1 \mathrm{~h}$ \\
\hline Ilorin [this study] & $11.12 / 4.25$ (mean) & $1 \mathrm{~h}$ \\
\hline
\end{tabular}

\section{CONCLUSIONS}

With the monitoring done consecutively for 3 years covering the two seasons and the data generated subjected to spatial and temporal assessments to have the results which provided estimate of the mean concentrations of sulfur dioxide day time trend over Ilorin air shed. Results confirmed that the technique could be used to obtain useful information to support air quality management decisions, as well as in-depth understanding of source strengths and potential impacts.

\section{AKNOWLEDGEMENTS}

We wish to thank Global Change System for Analysis Research and Training (START) USA for sponsoring this work.

\section{REFERENCES}

1. Albalak, R; Frisancho, A.R; Keeler, G.J. Thorax 1999, 54, 1004.

2. Gordan, J.M. Climate Change and Acid Rain, MITRE Corporation McLean: Virginia; 1985; pp 3-35.

3. O'Neill, P. Environmental Chemistry, 2nd ed., Chapman and Hall: Glasgow; 1993.

4. Dara, S.S. A Textbook of Environmental Chemistry and Pollution Control, S. Chand and Company Ltd.: New Delhi; 2004; 110055.

5. Jones, V.W. in Coal Desulfurization: High Efficiency Preparation Methods, Kawatra, S.K.; Eisele, T.C.; Timothy, E.C. (Eds.), Taylor and Francis: New York; 2001. 
6. IPCC (Intergovernmental Panel on Climate Change) McG Tegart, W.J.; Sheldon, G.W. (Eds), The supplementary Report to the IPCC Impact Assessment, Australian Government Publishing Service; 1992; p 112. Retrieved (1/11/2008) from http://www.ipcc.ch/ipccreports/assessments-reports.htm.

7. Ayodele, J.T.; Ahmed, A. The Environmentalist 2001, 21, 145.

8. Seinfield, J.H. Science 1989, 243, 745.

9. Abdul Raheem, A.M.O. Ph.D. Thesis, University of Ilorin, Nigeria; 2007.

10. Onianwa, P.C.; Fakayode, S.O.; Agboola, B.O. Bull. Chem. Soc. Ethiop. 2001, 15, 71.

11. World Health Organization (WHO) Sulfur dioxide, Environmental Health Criteria, WHO: Geneva; 1981.

12. ACGIH: American Conference of Governmental Industrial Hygienists Documentation of Threshold Limit Values and Biological Exposure Indices, Vol. 2, 6th ed., ACGIH: Cincinnati; 1991, pp 786-788.

13. Baumbach, G.; Vogt, U. Water, Air and Soil Pollution 2003, Focus 3, 65.

14. Molski, B.; Dmuchowski, W. Effects of Acidification on Forests and Natural Vegetation, Wild Animals and Insects in Acidification and Its Policy Implications, Schneider, T. (Ed.), Elsevier: Amsterdam; 1986; pp 29-51.

15. Bloomfield, P.; Royle, J.A.; Steinberg, L.J.; Yang, Q. Atmospheric Environ. 1996, 30, 3067.

16. Haagen-Smith, A.J. Ind. Eng. Chem. 1952, 44, 1342.

17. Nihlgard, B. Ambio. 1985, 14, 2.

18. Schutt, P.; Cowling, E.B. Plant Disease 1985, 69, 548.

19. ECE Effects of acidifying depositions and related pollutants on forest ecosystems, Executive Body for the Convention on Long-Range Transboundary Air Pollution, Third Session, Geneva; 5-9 March 1984.

20. Abdul Raheem, A.M.O.; Adekola, F.A.; Obioh, I.B. J. Appl. Sci. Environ. Mgt. 2006, 10, 5.

21. LaMotte User's manual for LaMotte air sampling pump and test kits. Chestertown, U.S.A; 2005.

22. Abdul Raheem, A.M.O.; Adekola, F.A.; Obioh, I.B. Environ. Model Assess. 2009, 14, 497.

23. Nyomarkay, K.M.; Fridralszky, L.; Szasz, I. Environ. Monit. Assess. 1982, 2, 435.

24. Bernars, L.N.; Mariette, J.G.; Cecile, M.A; Monique, J.S. Environ. Sci. Technol. 1999, 33, 217.

25. World Health Organization (WHO) Guidelines for Air Quality, WHO: Geneva; 1999.

26. European Environmental Agency (EEA) Exceedance of Air Quality Limit Values in Urban Areas, (CSI 004) Assessment 2006.

27. USEPA Revisions to the National Ambient Air Quality standards; Sulfur oxides, Federal Register 1997, 62138.

28. FEPA, Guidelines and Standards for Environmental Pollution Control in Nigeria, 1991; p 63.

29. EPA (Japan JEA) Motor Vehicle Pollution Control, 1986; pp 27-30.

30. World Resources An Assessment of the Resources Base that support the Global Economy with Data Tables on 146 Countries in Collaboration with the United Nations Environmental Programme, 1988-89, 10, 163.

31. Ghauri, B.; Lodhi, A.; Mansha, M. Environ. Monit. Assess. 2007, 127, 237. 